\title{
NUME DE LĂCAȘURI DE CULT ORTODOXE (HRAMURI) DIN AREALUL MARAMUREȘEAN
}

\author{
Mihaela Munteanu Siserman \\ Universitatea Tehnică din Cluj-Napoca, \\ Centrul Universitar Nord Baia Mare, România
}

SABIN SISERMAN

Filiala Județeană Maramureș a Asociației Comunelor din România

\section{Names of churches (patron saints) in Maramureș}

\begin{abstract}
Maramureş is a geographic area where the Orthodox Church (irrespective of rite), the Roman Catholic Church and the Greek-Catholic Church have manifested the conservative "force" of Romanian Christian spirituality, each in their own way and, in some cases, identically. The feast of the patron of a church is a religious ceremony in which the patron saint of the church is worshipped or in which an event reiterating a Christian religious episode is evoked. This is common practice as opposed to other ((Neo)Protestant) cults, which do not generally adopt such baptismal acts. The present study aims at identifying the correlations and alleged motives of the onymic choice of a community of believers for their church, in spatial-temporal determination (if confirmed), using statistical analysis tools and the Bravais-Pearson correlation analysis.
\end{abstract}

Keywords: patron saint, Orthodox Church, Greek-Catholic Church, statistics, correlation analysis.

\section{Introducere. Premise, modele de cercetare, limitări și particularități}

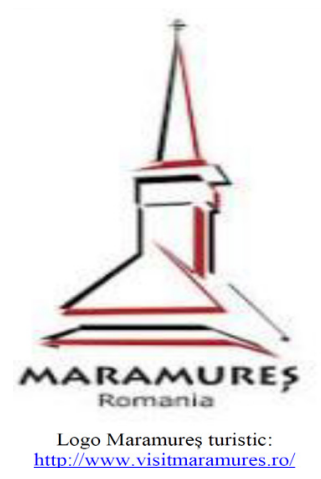

Prezentul studiu are la bază prelucrarea statistică și corelativă, prin indicii de corelație Bravais-Pearson, a informațiilor prezentate pe site-ul oficial al Episcopiei Ortodoxe Române a Maramureșului și Sătmarului, referitoare la numele bisericilor ortodoxe, aflate pe raza județului Maramureș ${ }^{1}$.

Baza de date creată nu include așezămintele monahale din același areal geografic, din rațiuni de omogenitate a informației statistice. Analiza întreprinsă a așezămintelor monahale din Maramureș va face obiectul unor „iradieri” viitoare ale cecetării onomastice, referitoare la întregul areal românesc.

1 Datele valorificate în prezenta cercetare sunt cele preluate din paginile aferente descrierii fiecărei Parohii ortodoxe din Maramureș, pe site-ul http://www.episcopiammsm.ro/ 
Cercetarea noastră privind dinamica fenomenului de numire a hramurilor bisericilor ortodoxe din județul Maramureș se fundamentează pe modelul coșerian privind evoluția unui fenomen sociolingvistic, model dezvoltat pe baza observațiilor lingviștilor Ferdinand de Saussure, Leiv Fydal și Alberto Mioni. Conform observațiilor acestora, pentru înțelegerea fenomenelor sociolingvistice, acestea trebuie analizate din mai multe perspective: temporală (diacronică), spațială (diatopică), evolutivă (diafazică), a mijloacelor specifice prin care acestea se realizează (diamesică) și a posibilităţii dezvoltării stratificate a fenomenului (diastratică). Analiza cumulativă prin prisma celor cinci factori de influență furnizează „consumatorului” de informație sociolingvistică o imagine sistemică și coerentă a fenomenului studiat, în integralitatea lui, și, poate, deschide căi de cercetare ulterioare, uzitând de tehnici de cercetare specifice altor domenii ale științei, în general ale statisticii și ale econometriei ${ }^{2}$.

Atunci când analiza sociolingvistică se adresează unei populații statistice determinate exhaustiv sau prin selecție (de regulă aleatorie, utilizând diverse tehnici de eșantionare), cercetarea după modelul coșerian poate fi extinsă prin analize de corelație de tip Bravais-Person. Acestea din urmă pun în evidență sensul și intensitatea cu care se manifestă fiecare dimensiune a fenomenului studiat, în raport cu evoluția acestuia în ansamblu, oferind cercetătorilor „uneltele” de bază în individualizarea rezultatelor şi în consolidarea concluziilor.

Prezentul studiu a pornit de la premisa posibilităţii creării unei baze de date complete a denumirilor de hramuri ale bisericilor ortodoxe din arealul maramureșean. Provocarea nu a fost simplă din cauza faptului că unele dintre bisericile aflate în administrația Episcopiei Maramureșului și Sătmarului au două ${ }^{3}$ sau chiar trei ${ }^{4}$ hramuri. Într-o asemenea conjunctură, pentru a nu afecta posibilele concluzii, s-a recurs la atribuirea unui singur hram fiecărei biserici (primul hram), cazurile precizate în notele de subsol fiind considerate excepții de la regulă.

În județul Maramureș se află în administrarea Episcopiei, prin cele cinci Protopopiate (Baia Mare, Sighet, Vișeu, Chioar și Lăpuș), un număr de 369 de lăcaşuri de cult (parohii, filii, capele), unele dintre acestea (îndeosebi cele în lemn sau cele cu structură de rezistență grav afectată) nefiind utilizate în mod sistematic în activitatea preoțească, slujbele regulate desfășurându-se în lăcașurile de cult în zid, consolidate.

O parte semnificativă a bisericilor maramureșene din patrimoniul Episcopiei, în

2 Metoda de cercetare statistico-econometrică a unui fenomen sociolingvistic, având la bază modelului coșerian descris mai sus, cu aplicabilitate în domeniul managementului întreprinderilor publice, a fost detaliat în Siserman (2016a: 87-106, 2016b), Munteanu Siserman, Siserman (2016: 292-299).

3 Sunt înregistrate cu două hramuri: Biserica din Recea Adormirea Maicii Domnului și Sfântul Ierarh Nicolae, Biserica din Ciocotiș cu hramurile Sfinții Arhangheli Mihail și Gavril, respectiv Sfinții Martiri Brâncoveni.

4 Cu trei hramuri: Biserica din Dragomirești cu hramurile Sfinții Români, Sfântul Ierarh Iosif Mărturisitorul și Acoperământul Maicii Domnului, respectiv Biserica din Posta cu hramurile Sfântul Prooroc Ilie Tesviteanu, Sfântul Ierarh Nectarie și Acoperamântul Maicii Domnului. 


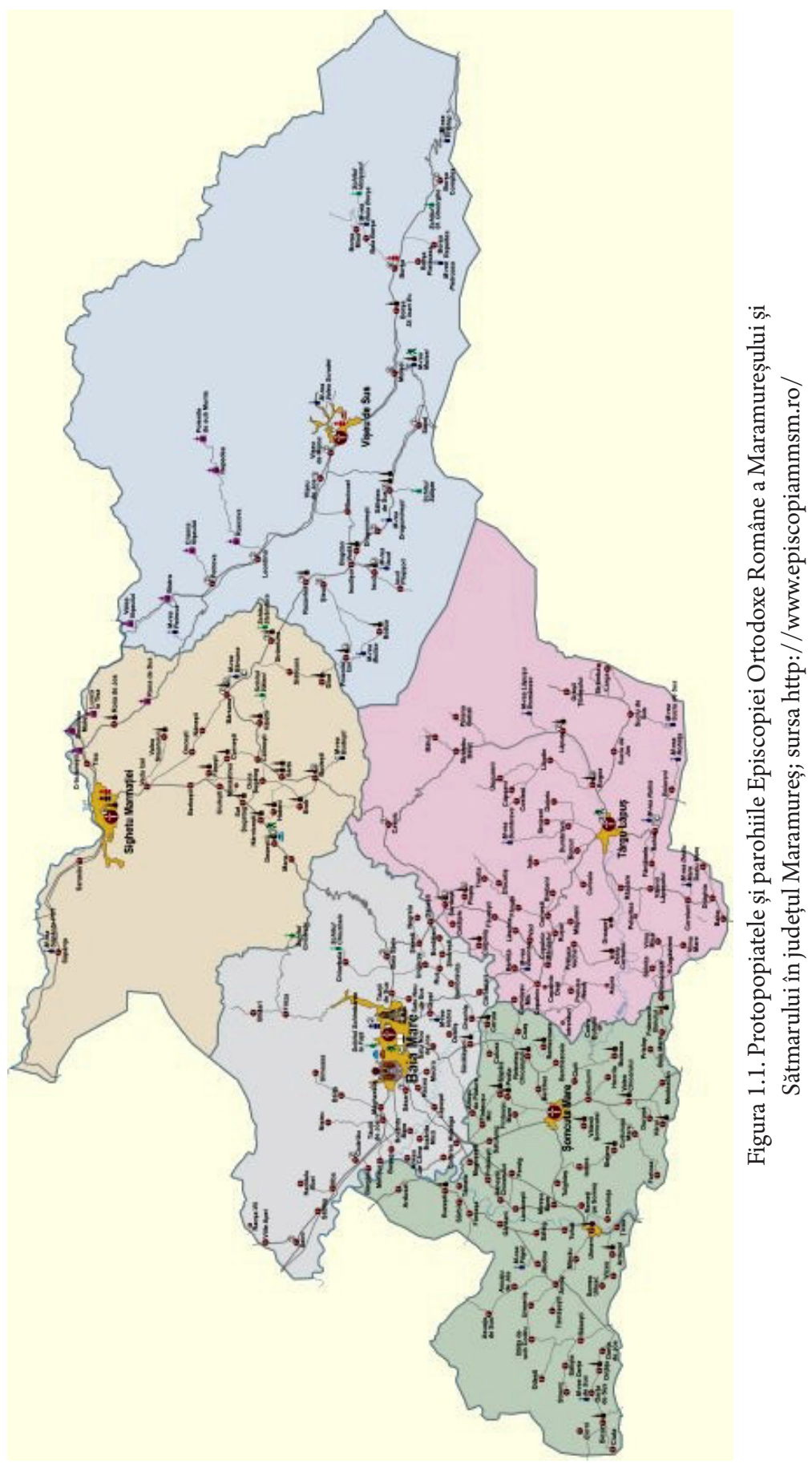


special cele din lemn, sunt înregistrate ca monumente istorice ${ }^{5}$, fiind însă, din cauza fondurilor insuficiente, în varii stări de degradare. Acestea pot avea (sau nu) același hram cu biserica de zid sau piatră din parohia respectivă, slujbele efectuându-se, în funcție de existența preoților necesari, fie numai într-un lăcaș de cult, fie în mai multe, pe raza aceleiași parohii. $\mathrm{O}$ categorie aparte de lăcașuri de cult o constituie bisericile și capelele, înființate, de regulă, după anul 1990, în diverse unități spitalicești ${ }^{6}$, unități militare $^{7}$ sau entități cu regim special ${ }^{8}$.

Site-ul Episcopiei Ortodoxe a Maramureșului și Sătmarului oferă informații privind numărul de enoriași care frecventează aproape toate parohiile și filiile din județ (cu excepția lăcașurilor de cult cu regim special), fără însă a detalia numărul de enoriași pe fiecare lăcaș în parte, fapt ce afectează, într-o oarecare măsură, cercetarea statistică referitoare la corelația între numărul enoriașilor din mediul rural / urban cu totalul entităților bisericești din județ.

Cele mai vechi biserici atestate documentar din Maramureș sunt: Nașterea Maicii Domnului din Ieud (UNESCO) (1364), Sfânta Cuvioasa Parascheva din Stegera (1400), Adormirea Maicii Domnului din Săcălășeni (1442) și Sfinții Arhangheli Mihail și Gavril din Sarasău (1456).

Din punct de vedere istoric, românii din Maramureș, ca de altfel și cei din alte zone ale Transilvaniei, Crișanei, Banatului și Bucovinei nu au beneficiat de conjuncturi istorice favorabile construcției unor lăcașuri de cult din piatră, românii fiind locuitori îndeosebi rurali, exilați extra muros de autorităţile vremii, fapt ce va conduce în timp la o veritabilă „cultură” a lemnului în cazul construirii de biserici (material perisabil, din nefericire) și nu numai. Acest aspect se perpetuează și în zilele noastre și se îmbină într-un mod armonios cu inegalabila „cultură a ospitalităţii” specifică locuitorilor din această zonă.

Studiul nostru nu vizează relația dintre hramurile bisericilor din Maramureș și datele la care se sărbătorește efectiv sfântul protector al bisericii, consecință a datelor „mobile” ale unor sărbători religioase, conexe cu comemorarea Învierii Domnului, deoarece astfel s-ar induce o relativitate accentuată a concluziilor eventualelor cercetări

5 Biserici UNESCO - 8 monumente cu hram propriu: Biserica de lemn din Budești Josani, Biserica de lemn din Desești, Biserica de lemn din Bârsana, Biserica de lemn din Poienile Izei, Biserica de lemn din Ieud Deal, Biserica de lemn din Șurdești, Biserica de lemn din Plopiș și Biserica de lemn din Rogoz.

6 Capele în spitale: Capela Spitalul Județean de Urgență „dr. Constantin Opriș” Baia Mare (fără hram), Capela Spitalului de Pneumofiziologie Baia Mare, cu hramul Sfinții Dr. Cosma și Damian, Capela Spitalului de Boli Infecțioase și Psihiatrie Baia Mare (fără hram), Capela Sfântul Mucenic Pantilimon din Policlinica II Baia Mare, Biserica din incinta Spitalului Municipal Sighetu Marmației și Capela Spitalului Orașenesc Borșa.

7 Biserica Sfântul Mucenic Gheorghe, Garnizoana Baia Mare, Biserica Sfinții Arhangheli Mihail și Gavriil din incinta Jandarmeriei, Biserica Sfântul Iosif cel Nou de la Partos, ISU Maramureș sau Biserica (făra hram) a Inspectoratului Teritorial al Poliției de Frontieră.

8 Entități cu regim special: Capela Penitenciarului Județean (hram nenominalizat pe siteul Episcopiei). 


\begin{tabular}{|c|c|c|c|}
\hline N.C. & NUME DE HRAMURI BISERICESTTI & DATA SĂRBĂTORII & $\begin{array}{c}\text { LĂCASE DE CULT } \\
\text { TOTAL }\end{array}$ \\
\hline 1 & Sfinții Arhangheli Mihail și Gavriil & 8 noiembrie & 120 \\
\hline 2 & Adormirea Maicii Domnului & 15 august & 28 \\
\hline 3 & Nașterea Maicii Domnului & 8 septembrie & 28 \\
\hline 4 & Sfinții Apostoli Petru și Pavel & 29 iunie & 26 \\
\hline 5 & Sfântul Nicolae & 6 decembrie & 21 \\
\hline 6 & Cuvioasa Parascheva & 14 octombrie & 16 \\
\hline 7 & Sfânta Treime & $\begin{array}{l}\text { dată mobilă - prima zi } \\
\text { după Rusalii }\end{array}$ & 15 \\
\hline 8 & Sfântul Dimitrie & 26 octombrie & 13 \\
\hline 9 & Sfântul Prooroc Ilie Tesviteanul & 20 iulie & 11 \\
\hline 10 & Sfinții Împărați Constantin și Elena & 20 mai & 9 \\
\hline 11 & Sfântul Gheorghe & 23 aprilie & 8 \\
\hline 12 & Duminica Tuturor Sfinților & $\begin{array}{l}\text { dată mobilă- prima } \\
\text { duminic- după Rusalii }\end{array}$ & 7 \\
\hline 13 & Pogorârea Sfântului Duh & $\begin{array}{l}\text { dată mobilă - } \\
\text { Rusaliile - } 50 \text { zile de la } \\
\text { Înviere }\end{array}$ & 7 \\
\hline 14 & Buna Vestire & 25 martie & 6 \\
\hline 15 & Înălțarea Domnului & $\begin{array}{l}\text { dată mobilă - a } 6 \text { joi } \\
\text { de la Înviere }\end{array}$ & 5 \\
\hline 16 & Nașterea Sfântului loan Botezatorul & 24 iunie & 5 \\
\hline 17 & Înalțarea Sfintei Cruci & 14 octombrie & 4 \\
\hline 18 & Z hram nedeclarat & & 4 \\
\hline 19 & Intrarea în Biserică a Maicii Domnului & 21 noiembrie & 3 \\
\hline 20 & Sfântul loan Botezatorul & 7 ianuarie & 3 \\
\hline 21 & Acoperământul Maicii Domnului & 1 octombrie & 2 \\
\hline 22 & Învierea Domnului & dată mobilă & 2 \\
\hline 23 & Schimbarea la Față & 6 august & 2 \\
\hline 24 & Sfânta Ana & 9 septembrie & 2 \\
\hline 25 & Sfântul Apostol Andrei & 30 noiembrie & 2 \\
\hline 26 & Sfântul Apostol Toma & data mobila & 2 \\
\hline 27 & Sfântul losif Mărturisitorul & 24 aprilie & 2 \\
\hline 28 & Sfinții Români & $\begin{array}{l}\text { dată mobilă- a 2-a } \\
\text { duminică după } \\
\text { Rusalii }\end{array}$ & 2 \\
\hline 29 & Duminica Mironosițelor & $\begin{array}{l}\text { dată mobilă - a 3-a } \\
\text { duminică după } \\
\text { Înviere }\end{array}$ & 1 \\
\hline 30 & Izvorul Tămăduirii & 2 februarie & 1 \\
\hline 31 & Nașterea Domnului & 25 decemnrie & 1 \\
\hline 32 & Sfinții Trei lerarhi & 30 ianuarie & 1 \\
\hline 33 & Sfântul loan Evanghelistul & $8 \mathrm{mai}$ & 1 \\
\hline 34 & Sfântul loan Valahul & $12 \mathrm{mai}$ & 1 \\
\hline 35 & Sfântul losif & 26 decembrie & 1 \\
\hline 36 & Sfântul losif cel Nou de la Partos & 15 septembrie & 1 \\
\hline 37 & Sfântul Mucenic Pantelimon & 27 iulie & 1 \\
\hline 38 & Sfântul Vasile cel Mare & 1 ianuarie & 1 \\
\hline 39 & Sfântul Voievod Ștefan cel Mare & 2 iulie & 1 \\
\hline 40 & Sfinții Dr. Cosma și Damian & 1 iulie & 1 \\
\hline 41 & Soborul Sfinților 12 Apostoli & 30 iunie & 1 \\
\hline \multirow[t]{3}{*}{42} & Tăierea Capului Sfântului Ioan Botezătorul & 29 august & 1 \\
\hline & NUMĂR DE HRAMURI BISERICEȘTI & & 42 \\
\hline & NUMAR DE BISERICI & & 369 \\
\hline
\end{tabular}

Figura 1.2. Situația hramurilor și a bisericilor ortodoxe din Maramureș (august 2017) 
corelative. De asemenea, analiza nu a putut lua în calcul schimbările de hram ale bisericilor, de-a lungul existenței lor, ca urmare a influenței evenimentelor istorice, cercetarea cuprinzând deci datele existente în acest moment (august 2017). Situaţia hramurilor bisericilor ortodoxe este prezentată mai sus.

Situația distribuției lăcașurilor de cult în arealul maramureșean ține seama de relieful muntos în partea de nord și de est a județului (unde densitatea bisericilor este mai rarefiată și urmează firul apelor curgătoare) și de o densitate mai mare în zonele depresionare ale Chioarului, Lăpușului și Băii Mari.

\section{Analiza diacronică}

Istoria bisericilor din Maramureș (și implicit a hramurilor acestora), agitată prin însăși destinul acestui loc, poate fi etapizată, ținând seama de câteva momente care au marcat inflexiuni în evoluția fenomenului religios ortodox:

- anul 1700 (și câțiva ani consecutivi), când s-a produs unirea Bisericii Ardelene (ortodoxă) cu Biserica Catolică;

- anul 1948, când Biserica Greco-Catolică este pusă sub interdicție de către autoritățile comuniste, lăcaşurile de cult fiind „retrocedate” Bisericii Ortodoxe Române, activitatea acesteia fiind coordonată și controlată de regimul comunist;

- anul 1989, când, odată cu căderea regimului comunist, este redată libertatea de credință, confesiunile religioase și riturile creștine separându-și patrimoniile treptat, uneori pe baza unor acțiuni în instanță de lungă durată, situație neîncheiată nici la momentul prezentei cercetări.

Pentru un număr de șase biserici nu se cunoaște data exactă a construcției sau târnosirii, două dintre acestea având hramul Sfinții Arhangheli Mihail și Gavril și câte un lăcaș cu hramul Sfinții Împărați Constantin și Elena, respectiv Duminica Tuturor Sfinților, Sfinții Apostoli Petru și Pavel, Nașterea Sfântului Ioan Botezătorul.

Bisericile construite (sau târnosite în perioada 1400-1700) sunt în număr de 32, cele mai frecvente hramuri comemorându-i pe Sfinții Arhangheli Mihail și Gavril (10 biserici), Sfântul Nicolae și Cuvioasa Parascheva (6 biserici), Adormirea Maicii Domnului (3 biserici) și Sfântul Ilie Tesviteanul, Nașterea Domnului, Sfântul Dimitrie (câte 2 hramuri).

Analiza statistică evidențiază faptul că marea mjoritate a bisericilor ortodoxe de azi au fost construite în perioada 1700-1948, numărul total al acestora (biserici în lemn sau zid) fiind de 199. Bisericile care au funcționat în perioada unirii Bisericii Ardelene cu Roma celebrează următorii sfinți și evenimente: Sfinții Arhangheli Mihail și Gavriil (84 lăcaşuri de cult), Nașterea Maicii Domnului (21 biserici), Sfinții Apostoli Petru și Pavel (18 biserici), Adormirea Maicii Domnului (15 biserici), Sfântul Nicolae (12 biserici).

$\mathrm{Cu}$ toate că regimul comunist nu încurajat asocierile de niciun fel, inclusiv cele religioase, Biserica Ortodoxă maramureșeană a beneficiat de susținere din partea statului, în perioada 1948-1989. Timp de 50 de ani, au fost ridicate 54 biserici, ritm întrecut doar după 1900, când, într-o perioadă de 27 de ani, s-au construit sau sunt încă în construcție, în diverse faze, 78 de biserici (în medie, 3 biserici pe an). 
Hramurile bisericilor construite (târnosite) în perioada comunistă au fost: Sfinții Mihail și Gavril (14 biserici), Adormirea Maicii Domnului (7 biserici), Sfânta Treime (7 biserici), Sfinții Apostoli Petru și Pavel (6 biserici) și Sfinții Împărați Constantin și Elena (5 biserici).

Bisericile construite după evenimentele din decembrie 1989 îi comemorează prioritar pe Sfinții Arhangheli Mihail și Gavril (10 biserici), Sfântul Gheorghe (6 biserici), Sfânta Treime și Sfântul Ilie (câte 5 biserici). Caracteristică acestei perioade este diversificarea sfinților protectori și închinarea unor biserici (îndeosebi cele construite în spitale, unități militare și penitenciare), unor sfinți mai puțin veneraţi în celelalte perioade, cum ar fi: Sfântul Iosif Mărturisitorul ${ }^{9}$ și Sfinții Români (câte 2 biserici), respectiv Duminica Mironosițelor, Izvorul Tămăduirii, Nașterea Domnului, Sfinții Trei Ierarhi, Sfântul Ioan Evanghelistul, Sfântul Ioan Valahul, Sfântul Iosif, Sfântul Iosif cel Nou de la Partos, Sfântul Mucenic Pantelimon, Sfântul Vasile cel Mare, Sfântul Voievod Ștefan cel Mare, Sfinții Dr. Cosma și Damian, Soborul Sfinților 12 Apostoli, Tăierea Capului Sfântul Ioan Botezătorul (câte o biserică).

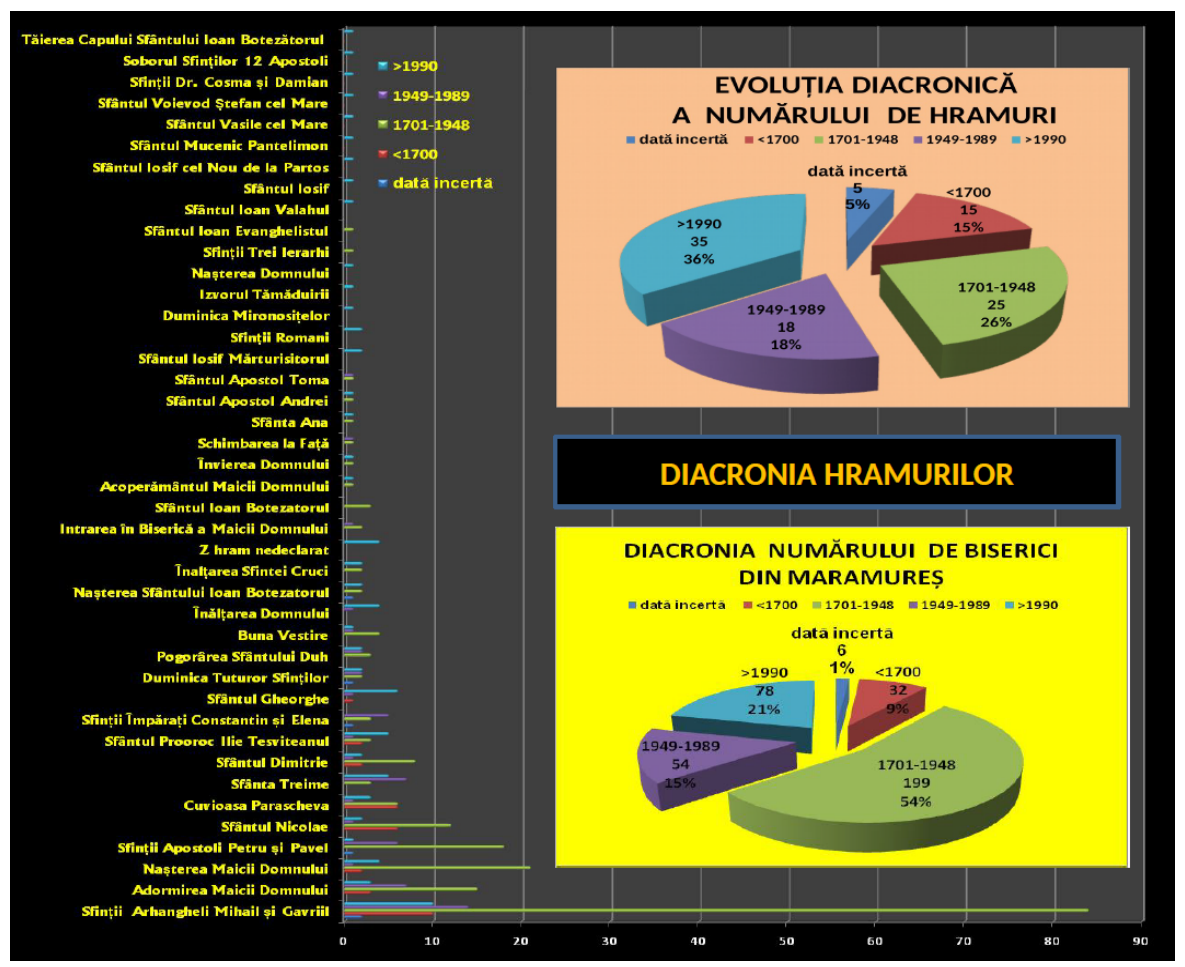

Figura 2.1. Situația hramurilor și a bisericilor ortodoxe din județul Maramureș, după anul construcției sau târnosirii

9 Episcop ortodox al ținutului Maramureșului între 1690-1710. (https://doxologia.ro/ viata-sfant/viata-sfantului-ierarh-iosif-marturisitorul-din-maramures). 


\section{Analiza diatopică}

Organizarea activității religioase în județul Maramureș se desfășoară prin cinci protopopiate: Baia Mare, Lăpuș, Sighet, Chioar și Vișeu. Cele 369 de entități de cult, care fac obiectul cercetării statistice, au o distribuție teritorială ce ține seama de moștenirea istorică, pe de o parte, și de politica de investiții a conducerii Episcopiei, pe de altă parte (vezi Fig. 3.1.). Din histograma 3.1, reprezentând sinteza pe protopopiate a numărului de biserici, se observă diatopica generală a fenomenului de numire a hramurilor bisericești, respectiv o concentrare mai numeroasă a lăcaşurilor de cult în zona Lăpușului (96 de unități bisericești) și a Chioarului ( 89 de biserici), în timp ce în protopopiatele Sighet și Vișeu, numărul lăcașurilor de cult este cu cca $40 \%$ mai mic (câte 52 , respectiv 57 de biserici).

O situație aparte o constituie zona Baia Mare, care, din punct de vedere al numărului de biserici, se situează undeva ușor peste media județeană (75 de unități de cult) şi în care, după evenimentele din 1989, a demarat un proces intensiv de ridicare a noi biserici ortodoxe.

În ceea ce privește numele acestor biserici, se observă predominanța masivă a hramurilor Sfinților Arhangheli Mihail și Gavriil în zonele Chioar (50 de biserici) și Lăpuș (36), în timp ce în zona Vișeu aceștia sunt venerați doar în două lăcașuri de cult, în zona Sighet în 12 biserici și în protopopiatul Baia Mare în 20 de unităţi bisericești.

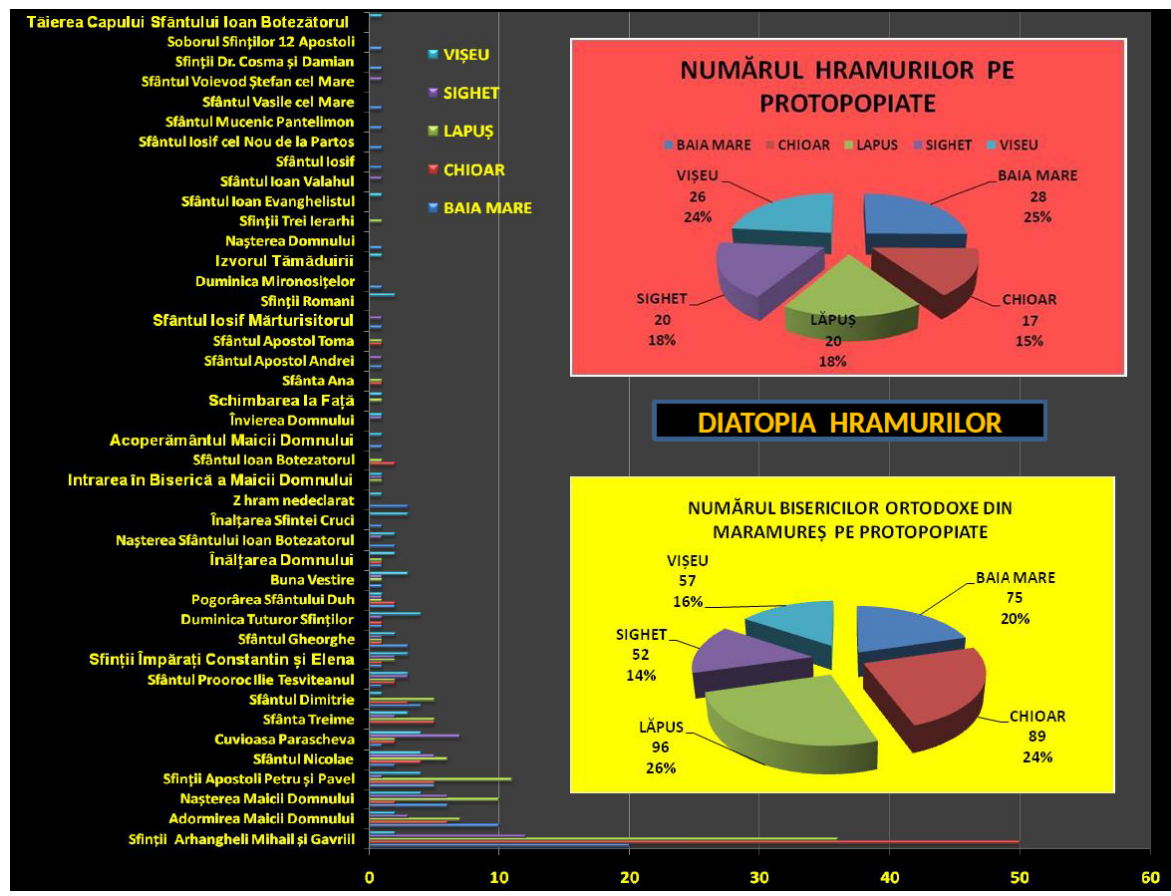

Figura 3.1. Distribuția hramurilor și a bisericilor ortodoxe în Maramureș, pe protopopiate 
Concentrări semnificative de biserici cu același hram se regăsesc, din punct de vedere diatopic, în Protopopiatul Lăpuș (11 biserici poartă numele Sfinții Apostoli Petru și Pavel și 10 - Nașterea Maicii Domnului); în Proptopopiatul Baia Mare, 10 biserici au hramul Adormirea Maicii Domnului, iar 6 biserici - Naşterea Maicii Domnului; Cuvioasa Parascheva este celebrată cel mai frecvent în bisericile din Protopopiatul Sighet (7 biserici), iar în Protopopiatul Chioar - Adormirea Maicii Domnului (6 biserici), Sfânta Treime și Sfântul Dimitrie (5 biserici).

Protopopiatul Vișeu se caracterizează printr-o eterogenitate pronunțată a numelor de hram, apropiată de cea a Protopopiatului Baia Mare, care prezintă diversitatea cea mai mare de sfinți celebrați prin atribuirea numelui lor unor biserici.

\section{Analiza diamesică}

Activităţile de cult se desfăşoară în prezent atât în lăcaşuri construite în piatră, cât și în lăcaşuri de cult din lemn ${ }^{10}$. Trebuie subliniată preponderența activităţilor religioase în biserici în zid, datorită protecției superioare a participanților la slujbe în aceste biserici, precum și a stării mai bune de întreținere, comparativ cu cele de lemn (vezi figura 4.1.).

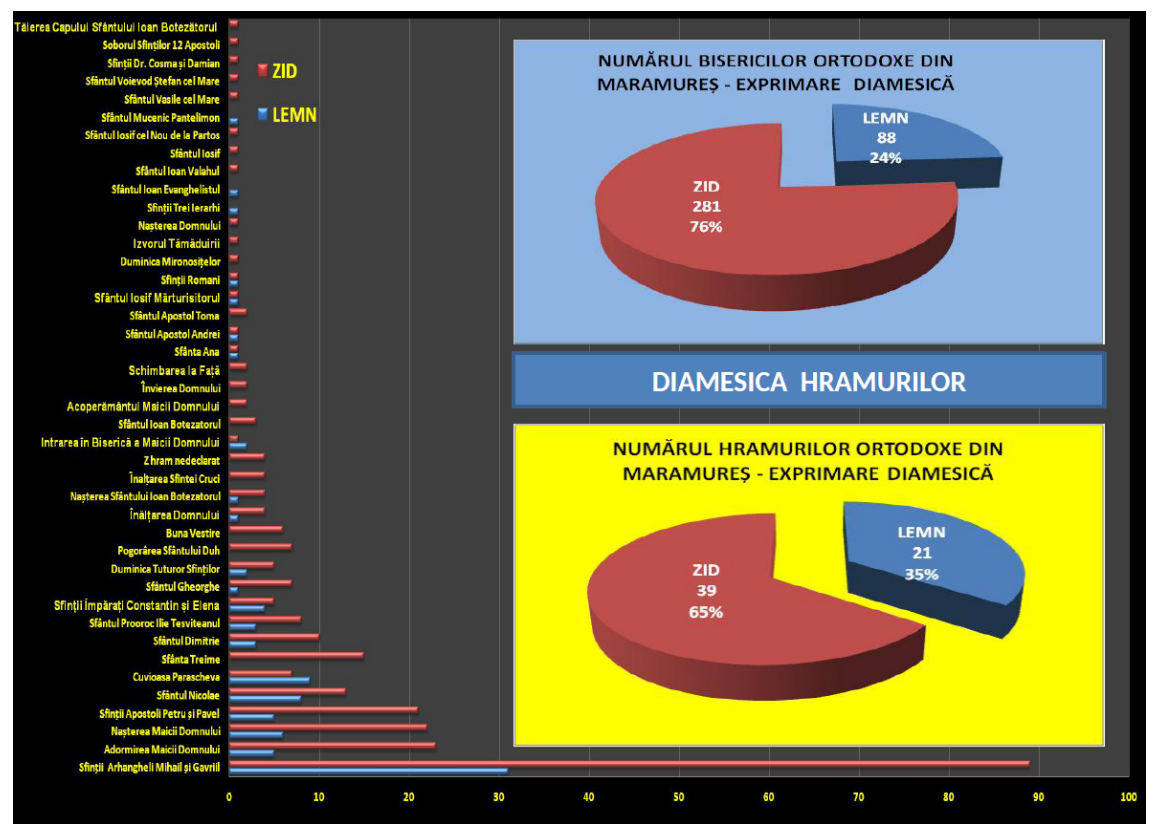

Figura 4.1. Distribuția hramurilor și a bisericilor ortodoxe în Maramureș, după materialul de construcție

10 Răchișan analizează (2015: 66-71) elementele motivice, de origine mitologică uneori (de exemplu, soarele antropomorfizat), prezente în sculptura populară și în pictura bisericilor de lemn din Maramureș, cu referință în special la Biserica de lemn „Sfinții Arhangheli Mihail și Gavril” (sec. al XVI-lea) din Rogoz și Biserica veche de lemn „Zămislirea Sfintei Ana” (sec. al XVII-lea). 
Numărul bisericilor de lemn din Maramureș reprezintă cca 25\% din totalul bisericilor existente ( 88 de lăcaşuri de cult), majoritatea fiind declarate monumente istorice. Histograma care oferă dimensiunea diamesică a fenomenului socioreligios de numire a bisericilor ortodoxe din Maramureș este prezentată în figura 4.2.

În ceea ce privește numele bisericilor, se observă o eterogenitate mai pronunțată a numelor de sfinți protectori ai bisericilor construite în zid. Primele 5 poziții ale numelor lăcașurilor de cult aparțin (în ordine descrescătoare) Sfinților Arhangheli Mihail și Gavriil (31 de biserici în lemn și 89 în zid), Adormirea Maicii Domnului (5 biserici în lemn și 23 în zid), Nașterea Maicii Domnului (6 biserici în lemn și 22 în zid), Sfinții Apostoli Petru și Pavel ( 5 biserici în lemn și 21 în zid), respectiv Sfântul Nicolae ( 8 biserici în lemn și 13 în zid). Este notabilă poziția dominantă a lăcaşurilor de cult cu hramul Sfânta Treime (15 biserici), construite exclusiv în zid.

\section{Analiza diafazică}

În determinare istorică, Maramureșul a fost o regiune agrară, existând puține „burguri” în zonele Baia Mare, Baia Sprie, Lăpuș, Vișeu, Chioar. Dezvoltarea accentuată a arealului cercetat, începând cu anii 1950, se datorează investițiilor masive în infrastructura economică, Maramureșul fiind renumit prin minerit și prin exploatarea lemnului. Consecința acestei stări se reflectă prin faptul că unele comunități rurale au fost ridicate la rang de oraș, în prezent județul având două municipii și 11 orașe. Mediul rural este reprezentat administrativ-teritorial prin 63 de comune, care concentrează un număr total de 170 de sate.

Hramurile bisericilor, după apartenența la mediul urban, respectiv rural, așa cum este în prezent organizarea administrativ-teritorială a județului Maramureș, sunt prezentate în tabelul 5.1. Situația centralizatoare evidențiază dimensiunea diafazică a fenomenului de numire a lăcaşurilor de cult, net în favoarea celor din mediul rural, care cumulează $82 \%$ din numărul total al bisericilor județului.

Din punct de vedere al concentrării numelor de hram, observăm că Sfinții Arhangheli Mihail și Gavril denumesc 114 biserici din mediul rural ${ }^{11}$ și pentru 6 în mediul urban, Adormirea Maicii Domnului este hram pentru 24 de biserici din mediul rural și pentru 4 în mediul urban, Nașterea Domnului - 24 în mediul rural și 4 în mediul urban, Sfinții Apostoli Petru și Pavel - 20 în mediul rural și 6 în mediul urban, Sfântul Nicolae - 19 biserici în mediul rural și 2 în mediul urban. Cuvioasa Parascheva este venerată prin hram în 15 lăcașuri de cult din mediul rural și doar într-o biserică din mediul urban.

11 Oliviu Felecan și Nicolae Felecan (2013: 194) încearcă să găsească o motivație a predominanței hramului Arhanghelii Mihail și Gavril (celebrați în data de 8 noiembrie), atât în cazul Bisericii Ortodoxe, cât și a celei Greco-Catolice: „Two explanations can be provided: on the one hand, when people's lives were a church so that it could be celebrated when agricultural activities were completed or during a more relaxed period. On the other hand, there is the belief in the help that the two angels give to communites of devotees, a custom that endures from medieval times, when the Romanian territory was subject to frequent turkish and tatar invasions". 


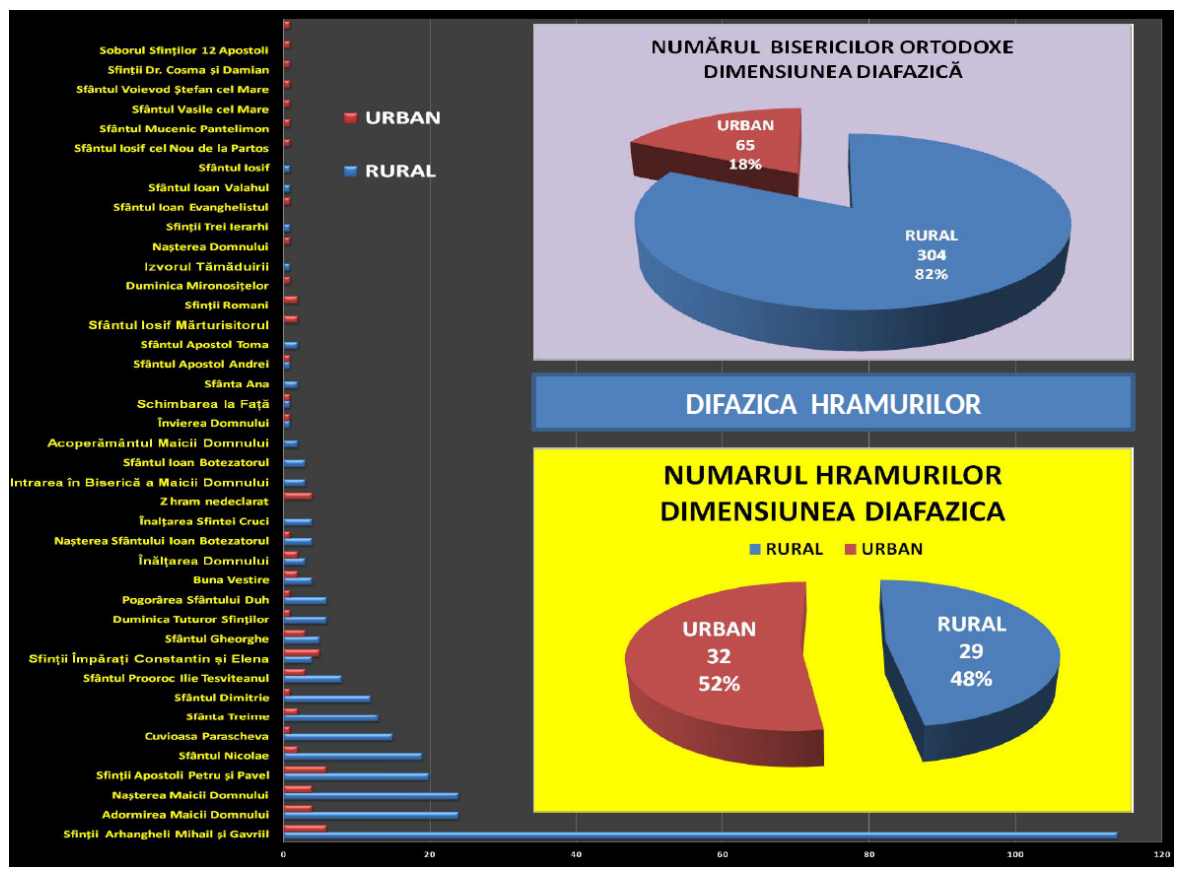

Figura 5.1. Distribuția hramurilor și a bisericilor ortodoxe din Maramureș, după mediul social

Trebuie evidențiată eterogenitatea pronunțată a hramurilor bisericilor din mediul urban, lăcașurile de cult nou înființate primind nume ale unor sfinți mai puțini cunoscuți comunității tradiționale ortodoxe: Sfântul Iosif cel Nou de la Partos, Sfântul Mucenic Pantelimon, Sfântul Vasile cel Mare, Sfântul Voievod Ștefan cel Mare, Sfinții Dr. Cosma și Damian, Soborul Sfinților 12 Apostoli, Tăierea Capului Sfântul Ioan Botezătorul, aceste hramuri aparținând exclusiv unor biserici din mediul urban maramureșean.

\section{Analiza diastratică}

Bisericile ortodoxe care ființează în județul Maramureș se adresează, conform datelor preluate din site-ul oficial al Episcopiei Maramureșului și Sătmarului, unui număr de 330801 de enoriași, structura etnică a județului stabilită cu ocazia recensământului din 2011 evidențiind o populație de naționalitate română de 374488 locuitori (vezi figura 6.1.). Fenomenul diastratic religios (stratificarea socială căreia i se adresează serviciile religioase) evidențiază o pondere de $54 \%$ a enoriașilor din mediul rural și de 46\% din mediul urban (vezi figura 6.2.).

Din punct de vedere al hramurilor lăcașurilor de cult, care concentrează peste 10000 de enoriași, cele mai frecventate sunt: Sfinții Arhangheli Mihail și Gavriil (70426 enoriași), Adormirea Maicii Domnului (29553), Nașterea Maicii Domnului (27672), Sfinții Apostoli Petru și Pavel (25915), Sfântul Nicolae (19486), Cuvioasa Parascheva 
(14854), Sfânta Treime (13938), Sfântul Prooroc Ilie Tesviteanul (12168) și Buna Vestire (11659).

Trebuie menționat faptul că bisericile în construcție și cele care funcționează în instituții sau entități speciale nu au comunicat numărul enoriașilor, dată fiind starea de provizorat în care oficiază slujbele sau prezența la serviciu religios a unor persoane aflate doar ocazional sau conjunctural în proximitatea acestor lăcașuri de cult.

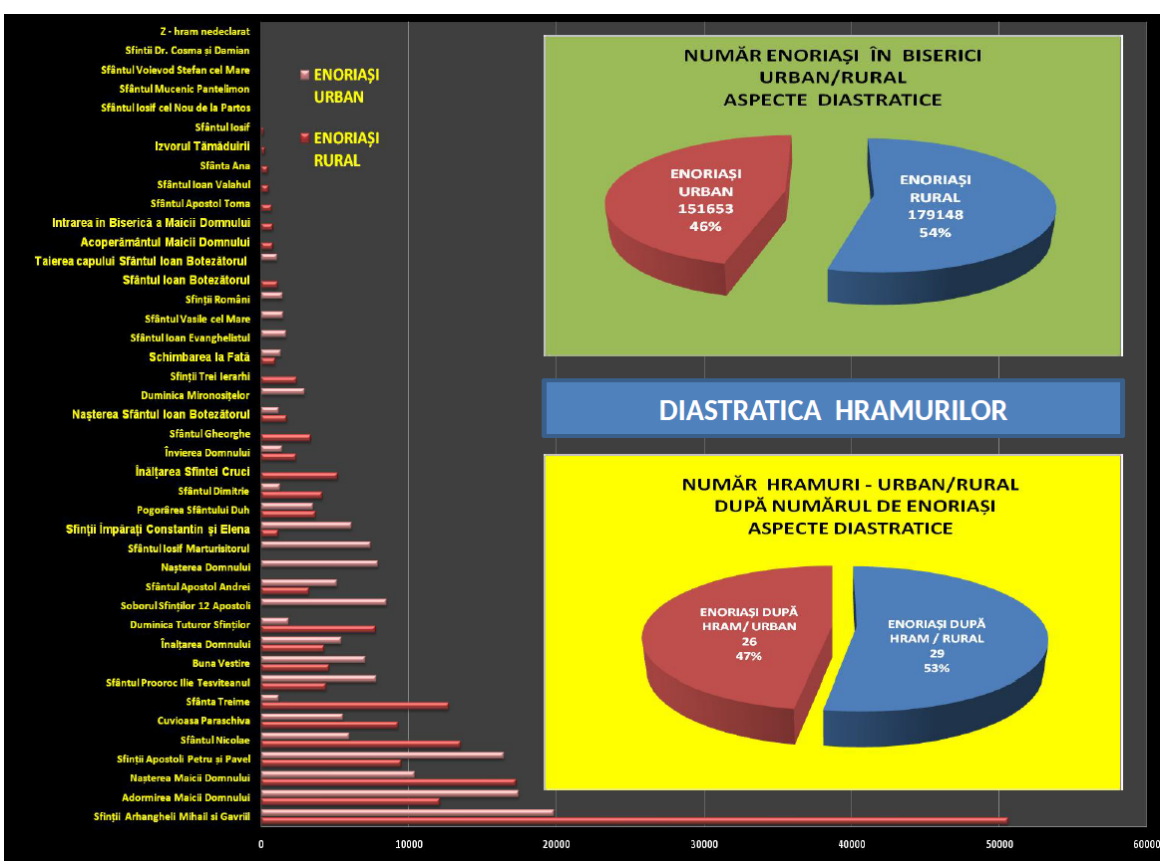

Figura 6.1. Distribuția hramurilor și a bisericilor ortodoxe în Maramureș, după numărul de enoriași

\section{Corelatiile de tip Bravais-Pearson}

Corelațiile de tip Bravais-Person pun în evidență sensul și intensitatea legăturilor existente între fenomenul luat în considerare în ansamblu, prezentat sub forma unor serii statistice ordonate după anumite criterii (în cazul de față, numărul total de hramuri) și fenomenul studiat din anumite puncte de vedere (diacronic, diatopic, diafazic, diamesic și diastratic, fiecare dintre acestea, detaliate, la rândul lor, în funcție de anumite caracteristici specifice, dar prezentate sub aceeași formă a seriei statistice de bază).

Indicele de corelație Bravais-Pearson poate varia în ecartul $[-1,1]$, divizat în subsegmentele $\left[-1,0^{\prime}\right]$, caz în care indicii evidențiază corelații de sens invers între seriile statistice analizate, respectiv $[0,+1]$, situație în care sunt ilustrate corelațiile directe. 
Intensitatea corelației între seriile statistice analizate este determinată de „modul” indicelui, Bravais-Pearson ${ }^{12}$ calculat astfel:

a) Dacă:

- $\mathrm{r} \in[0 ; 0.2] \rightarrow$ corelație foarte slabă;

- $\mathrm{r} \in[0.2 ; 0.4] \rightarrow$ corelație slabă;

- $r \in[0.4 ; 0.6] \rightarrow$ corelație rezonabilă;

- $\mathrm{r} \in[0.6 ; 0.8] \rightarrow$ corelație înaltă;

- $r \in[0.8 ; 1] \rightarrow$ corelație foarte înaltă;

b) Dacă: $r_{=}+1 /-1$, seriile sunt identice, de același sens sau de sens invers;

c) Dacă $r_{=} 0$, între seriile analizate nu există nicio corelație.

Calculul indicilor Bravais-Pearson pentru seriile statistice reprezentând hramurile bisericilor ortodoxe maramureșene, selectate după diverse criterii și seria ce vizează totalitatea hramurilor bisericilor din Maramureș a returnat următoarele valori subunitare:

\begin{tabular}{|c|c|c|c|c|c|c|}
\hline COVARIANȚA DIAFAZZICÃ & TOTAL & RURAL & URBAN & \multirow{6}{*}{\multicolumn{3}{|c|}{$\begin{array}{l}\text { INDICI DE CORELATIIE ÎN ONOMASTICA } \\
\text { HRAMURILOR BISERICILOR ORTODOXE DIN } \\
\text { MARAMURES }\end{array}$}} \\
\hline INDICEB.P & 1.000 & 0.998 & 0.649 & & & \\
\hline COVARIANTTA DIAMESICÄ & & LEMN & 210 & & & \\
\hline INDICEB.P & 1.000 & 0.965 & 0.996 & & & \\
\hline COVARIANȚA DIASTRATICĂ & & ENORIASI RURAL & ENORIASTI URBAN & & & \\
\hline INDICE B-P & 1.000 & 0.973 & 0.715 & & & \\
\hline COVARIANTA DIATOPICĂ & & BAIAMARE & CHIOAR & LĂPUȘ & SIGHET & VISTEU \\
\hline INDICE B.P & 1.000 & 0.937 & 0.969 & 0.987 & 0.866 & 0.359 \\
\hline COVARIANȚA DIACRONICĂ & & necunoscut & înainte de 1700 & $1700-1948$ & 1949-1989 & dupa 1990 \\
\hline INDICE B.P & 1.000 & 0.715 & 0.837 & 0.990 & 0.864 & 0.746 \\
\hline
\end{tabular}

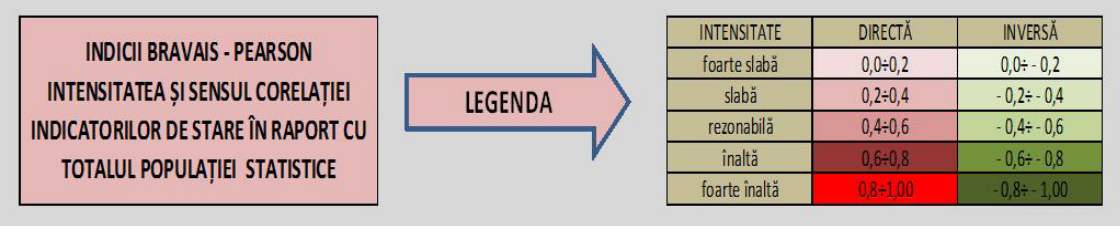

Figura 7.1. Corelații și intensități referitoare la hramurile bisericilor ortodoxe maramureșene

\section{Concluzii}

Analiza corelativă, considerând ca serie de bază (faţă de care se analizează intensitatea și eventuala dependență funcțională) cea care reprezintă totalitatea hramurilor lăcașurilor de cult ortodoxe din județul Maramureș, evidențiază următoarele:

(i) Din punct de vedere diacronic (momentul edificării sau târnosirii lăcașurilor

12 https://easyspps.wordpress.com/2010/08/30/coeficientul-de-corelatie-al-lui-pearson-r-11/ 
de cult), indicii de corelație între seria de bază și cele cinci serii de timp în care au fost construite sau târnosite aceste biserici, ilustrează:

a. corelații directe și foarte înalte ca intensitate în cazul perioadelor de timp [1400-1700], [1701-1948] și [1949-1989];

b. corelații directe și rezonabile ca intensitate în cazul bisericilor ortodoxe pentru care nu se dețin informații referitoare la anul edificării sau târnosirii lor, precum și pentru bisericile construite după anul 1990.

Această situație se explică prin faptul că o parte destul de semnificativă a bisericilor nou ridicate au hramul unor sfinți mai puțin venerați în perioada 1400-1989.

(ii) Din punct de vedere diatopic (apartenența la o zonă geografică, respectiv de administrare printr-un anumit protopopiat), indicii de corelație Bravais-Pearson cu seria de bază reliefează:

a. corelații directe şi de intensitate foarte înalte în cazul hramurilor bisericilor din protopopiatele Baia Mare, Chioar și Lăpuș;

b. corelații directe și de intensitate înaltă în cazul protopopiatului Sighet;

c. corelație directă și de intensitate slabă în cazul protopopiatului Vișeu.

Explicația pentru situațiile b) și c) constă în faptul că în protopopiatele Sighet și Vișeu au fost demarate, după evenimentele din 1989, lucrări de construcții de biserici semnificative și au fost târnosite biserici cu nume de sfinți sau evenimente christice mai puțin „tradiționale”.

(iii) Din punct de vedere diamesic (natura materialelor utilizate la construcția lăcaşurilor de cult), indicii Bravais-Pearson evidențiază:

a. o corelație directă de intensitate foarte înaltă, uşor mai pronunțată în cazul bisericilor construite în zid față de cele din lemn, consecință a faptului că numărul bisericilor în zid este de cca trei ori mai mare decât cel al bisericilor din lemn.

(iv) Din punct de vedere diafazic (apartenența bisericilor la mediul rural sau urban), indicii Bravais-Pearson prezintă:

a. o corelație directă și foarte intensă în cazul lăcaşurilor de cult din mediul rural;

b. o corelație directă și de intensitate rezonabilă în cazul bisericilor din mediul urban.

Această stare de fapt poate fi explicată prin conservatorismul comunităților rurale și deschiderea comunităților urbane față de schimbare, odată cu târnosirea unor noi lăcașuri de cult.

(v) Din punct de vedere diastratic (stratificarea numărului enoriașilor care frecventează lăcașurile de cult agregați după hramul bisericii și apartenența la mediul rural sau urban), indicii Bravais-Pearson ilustrează:

a. o corelație directă și foarte înaltă în cazul bisericilor cu enoriașii din mediul rural;

b. o corelație directă și înaltă în cazul bisericilor cu enoriașii din mediul urban;

Concluzia generală a studiului corelativ privind denumirea hramurilor bisericilor ortodoxe din județul Maramureș evidențiază o stare de puternic consevatorism onomastic pe toate cele cinci planuri variaționale posibile (diacronic, diatopic, diamesic, 
diafazic și diastratic), cu uşoare „abateri” de la „tradiții” mai ales în cazul bisericilor din mediul urban sau a celor nou construite. Această tendință „,centrifugă” atitudinii ortodoxe conservatoare pare să dea semnalul schimbării și modernizării inclusiv în cazul bisericii ortodoxe române din judetul Maramureș.

\section{Bibliografie}

Aghelache, C. 2008. Statistică teoretică şi economică: sinteze şi studii de caz. București: Artiflex. Felecan, O. și N. Felecan. 2013. Names of Romanian Places of Worship. În Onomastics in Contemporary Public Space, Oliviu Felecan, Alina Bugheșiu (eds.), 186-206. Newcastle upon Tyne: Cambridge Scholars Publishing.

Munteanu Siserman, M. și S. Siserman. 2016. Extensii ale „brandului” coşerian în analize economice. În Magistri et alumni, amore scribendi. Studia In honorem Professoris Nicolae Felecan, Oliviu Felecan, Daiana Felecan (ed.), 292-299. Cluj-Napoca: Mega, Argonaut.

Răchișan, D.-A. 2015. Mitologia românească și estetica artei tradiționale din Maramureș. București: Editura Academiei Române.

Rotariu, T., G. Bădescu, I. Culic, E. Mezei şi C. Mureşan. 1999. Metode statistice aplicate in știintele sociale. Iași: Polirom.

Siserman S. 2016a. Model for the diagnosis of management quality in public enterprises. Revista de Management și Inginerie Economică 15 (2/60): 324-354.

Siserman, S. 2016b. Managementul de criză al entităţilor economice cu capital majoritar public deținut de unităţile administrativ-teritoriale, vol. I Fundamente teoretice. Cluj-Napoca: Mega.

\section{Surse}

Cristea, G. 1989. În țara bisericilor de lemn. Sibiu: Editura Mitropoliei Ardealului.

Biserici, mănăstiri şi schituri din România. 2009. Ed. a 4-a, revăzută. București: House of Guides. http://www.episcopiammsm.ro/ (accesat în august 2017).

Logo-ul Maramureșul turistic a fost realizat de Adelina Bolot și de Flaminiu Taloș, din Cluj-Napoca

https://www.emaramures.ro/maramuresul-turistic-va-avea-ca-stema-o-biserica-din-lemn/ (accesat în august 2017).

https://easyspps.wordpress.com/2010/08/30/coeficientul-de-corelatie-al-lui-pearson-r-11/ (accesat în august 2017). 